\title{
Effect of Job Status, Gender, and Employees' Achievement Motivation Behavior on Work Performance: a Case Study of Selected Local Government Employees in Ekiti State, Nigeria
}

\author{
Adedeji J. Ogunleye, \\ Damilola A. Osekita \\ Department of Psychology, Faculty of Social Sciences, \\ Ekiti State University, Ado Ekiti, Nigeria
}

doi: 10.19044/esj.2016.v12n26p235 URL:http://dx.doi.org/10.19044/esj.2016.v12n26p235

\begin{abstract}
This study investigated the effect of job status, gender, and employees' achievement motivation behavior on work performance. Two hundred and seven (207) local government employees' opinions were sampled using the achievement motivation questionnaire and the perceived work performance questionnaire. Seven hypotheses were developed and tested using $2 \times 2 \times 3$ Analysis of Variance (ANOVA) statistics. Results confirmed that job status $[\mathrm{F}(2,206)=5.05, \mathrm{p}<.05]$ and employees' achievement motivation behavior $[\mathrm{F}$ $(1,206)=2.34, p<.05]$ significantly affected employees' work performance. It also showed that gender do not have a significant effect on the work performance of employees $[\mathrm{F}(1,206)=.005, \mathrm{p} .>05]$. A significant interaction effect of gender and job status; gender and level of achievement motivation behavior; and job status and level of achievement motivation behavior were also found on work performance. However, there was no significant interaction effect that existed between gender, job status, and the level of achievement motivation behavior on work performance $[\mathrm{F}(2,206)=.217$, $\mathrm{p}>.05]$. Findings were discussed in the light of available literature and it is recommended that efforts should be made to discourage discriminative behavior among sexes while also closing gaps in level managers' hierarchies and categorizations. This is particularly in terms of derivable incentives, benefits, and pay on their jobs to have a significant impact on the work performance of employees.
\end{abstract}

Keywords: Job status, Gender, Employees' achievement motivation behavior, Work performance, Local Government Employees, Ekiti State 


\section{Introduction}

An organization is a social situation where human and material resources are co-ordinated to achieve set objectives. However, such objectives usually concern effectiveness, efficiency, productivity, and profit making in the case of profit oriented organizations. Unless the members of an organization are doing their jobs, the organization will ultimately fail.

Employees in the Local Government Councils are members of the organization who are expected to deliver services to people within the Local Government Area, which is a third tier of Government in Nigeria.

Blumberg and Pringle (1982) proposed a model of work performance that tries to improve on the traditional performance equation (i. e. Performance = Ability X Motivation). This was done by attempting to incorporate the full range of individual and environmental variables, which interact to produce the level and quality of work performance. Thus, this model consists of three components: Opportunity, Capacity, and Willingness to perform.

In spite of the fact that equal opportunities for men and women have been a priority in many countries, enormous gender differences prevail in most competitive and high-ranking positions (Niederle \& Vesterlund, 2008). This portends that the 'glass ceiling effect' in which women are prevented from occupying certain high ranking positions still exist in some cultures. In addition, the existence of such discriminative tendencies may thus mean that the discrimination against gender may, sometimes, be uncommitted, unwilling, and lackadaisical in their attitude to work and consequent work performance.

Okolo (1985) noted that in 1982, out of 8,350 lawyers in Nigeria, only 1005 (12.04\%) were women. Out of 204 high court judges in 1983, only 12 (3.94\%) were women. The Annual Abstract of Statistics (AAS, 1997) indicated that in 1992, only 45,881 females against 145,448 males were in the service of federal ministries in Nigeria. In 1993, the federal civil service employed only 47,426 females as against 149,645 males. In 1992/93 academic session, 80 female Professors as against 1,315 male Professors were in Nigeria Universities. Umar (1996) explain that in any traditional Nigeria community, it is stereotypically believed that the place of the girl-child and consequently women, is in the kitchen or at home and she is socialized into accepting her traditional roles of bearing and rearing children, and of maintaining the welfare of the family. Thus, women are seen as weaker sex who could not perform at equal levels with their male counterparts. They are denied opportunities to display their talents and potentials as they are stigmatized as lazy. However, divergent views have been expressed on the issue of sex and performance at work.

Broverman, Broverman, Clarkson, Rosenkrantz, and Vogal (1970) conducted a study on the sex-role characteristics of matured, healthy, and 
socially competent adults. The study indicated that both men and women agreed that competence was more of the characteristic of healthy male respondents than healthy females. Healthy females are different from healthy males, according to these scholars, because they are submissive, less independent, less adventurous, more easily influenced, less aggressive, less competent, more emotional, more concerned about their appearance, and they are more prone to having their feelings hurt. Similarly, Maccoby and Jacklin (1974) observed gender differences between boys and girls in four major areas, which are: (a) verbal ability, (b) visual and special ability, (c) mathematical ability, and (d) aggressiveness.

Good performance was viewed to be more related to the men than women. However, Champion, Kurt, Hastings and Harris (1984) noted that many of the characteristics that were associated with being male or females' reflect cultural beliefs and practices rather than fundamental differences. They noted that people were taught gender roles at the early stage of their lives, and these roles reflect the status of the position that they are expected to play. This assertion was supported by Uwe (1999) who found that male and female workers did not differ significantly in their vocational orientation within the realistic, investigative, enterprising, and conforming vocational group. Also, Scheresky (1976) studied personality characteristics and skills of their subjects in different occupations. Therefore, the study revealed that the prestige level of various personal characteristics, including gender, associated with occupation was frequently cross-culturally stereotyped. Similarly, Knudson (1982) studied whether women trained in management were as assertive and as competent in their jobs as men with similar training. The results of the study indicated that women were as assertive as men and performed equally well on their jobs as their men counterparts. Knudson stated that female were as able as men if given similar exposure.

Brown and Corcoran (1997) argued that one possible explanation for the significant increase in the gender gap in performance when assessing worker's performance is the risk-attitude. Other studies that set out to give reasons for gender differences in job performance came up with results that seem to be mixed with possibly higher degree of risks aversion among women. Lynn, Cao, and Horn (1996), for example, found that men's performance increased with career stage measured as professional tenure. However, they did not find a correspondent effect among women. Similarly, Larwood and Gutek (1989) argued that the model of men's career is simple, and can be seen as continuous development; whereas the career development of women should be characterized as disjointed.

Orestein and Isabella (1990) also argued that women do not adhere to the traditional model of career development because women's careers are interrupted more frequently than that of men. This is mainly because of 
childbearing and child rearing. According to the researchers, the general idea is that, because of the relatively disjointed character of women's career development, which is mainly caused by more interruptions, the influence of professional tenure on their performance will be less strong than it is for men.

Ajala (2004) posit that gender may affect work role and have ramifications for leadership training. According to the scholar, older male executive may be more communal in their work roles, while younger male manager are more agile. Fagenson (1990) report that women and men in upper management see themselves as similar with respect to masculine attributes. In order to advance within power structure, older female executive tends to become more effective and responsive to management training programmes. Thus, they have a more male orientation. At the same time, male become more communal as can be seen in mentoring younger people and sponsoring organizational development programmes.

An employees' job status is the actual ranking that exist in a work environment which may sometimes be in levels or grades. In Local Government Councils in Ekiti State, Nigeria, both level and grade are used together to rank an employee. Thus, officers on grade levels 1-6 are classified as lower level officers, while those on grade levels 7-12 and 14-17 are classified as middle and top level officers, respectively.

According to Sidanius and Pratto (1999), we live in a world full of benchmarks, categorizations, rankings, and hierarchies. Many managers think that categorizing workers and giving them feedback on their performance in work situations inspires them to become more competitive, work harder, to catch up, or excel even more. In fact, the opposite may also happen wherein workers become complacent, docile, and de-motivated because of their rankings and categorization. People who are ranked high and given senior positions may think that since they are atop, why try harder in terms of work performance again. On the other hand, those ranked low may become depressed about their work and give up.

Job performance has been described as the accomplishment of assigned duties in accordance with organizational guidelines subject to the normal constraints of reasonable utilization of available resources (Jamal, 1984). According to Clark (2000), effective work performance is the production of valid results in a work organization. It is when employees produce expected results that may lead to productivity in the work organization. Effective job performance has positive effects on both an organization and its employees. For the organization, it is a means by which it ensures economic growth and survival. Similarly, effective job performance provides the employees with economic gains, security, social status, family and social prerogatives, medical benefits, and educational opportunities (Adana, 1986). 
Workers achievement motivation behavior is based on reaching success and achieving aspiration in life. Also, achievement goal can affect the way a person performs a task and represent a desire to show competence (Harackiewicz, Barron, Carter, Lehto, \& Elliot, 1997). Achievement motivation behavior in performance differs in the extent to which an employee pursues challenging goals. Furthermore, the achievement motive refers to the desire to do well relative to the standard of excellence (McClelland, 1985). Workers with high-achievement motivation tend to be more realistic in their career aspiration than workers with low-achievement motivation. Workers with high-achievement motivation set personal goals that are challenging but attainable, whereas those low in achievement motivation tends to set goals either extremely easy or almost impossible. An employee who is high in achievement motivation need or tend to set very high goal for his/her work and he/she encourage persistence. This employee discourages him/herself from complaining or making excuses for performance and encourages him/herself to try harder. Achievement motivation and job performance are like two sides of a coin and are intertwined and interdependent. Both are a matter of interest of different parties since any employee will be willing to consolidate on the satisfaction derivable from performance of his or her tasks (Adeyemo \& Aremu, 1999).

In the mid 50s, Abraham Maslow, a noted psychologist, in his book 'Motivation and Personality' (1954), presented the view that a person's basic needs act as a motivator. The minimum needs that motivate people are their physiological, safety and social needs. In order to perform adequately and to have any measure of pleasure on jobs, these basic needs must be met. After they are met, ego and esteem needs emerge and serve as motivators. These include the need for recognition, respect, and status. Employees who seek to have their ego needs met, may thus, aspire to do jobs more proficiently or more creatively.

The highest level need, that is, the need for self-actualization, is the desire to live to potential, realize one's own ability, and exercise creativity. Due to the fact that these needs form the center of motivation, managers and organizations are always encouraged to provide the necessary condition, impetus, and/or the needs of their employees' to enable them strive for achievement.

The motive to achieve, therefore, seems to be at the core of work performance. In an attempt to ascertain the above position and armed with available literature and anecdotal evidences, this study is therefore poised to find out the influences of job status, sex differences, and employees' achievement motivation behavior on their work performances. 


\section{Methods \\ Participants}

The research participants used in this study were Ekiti State Local Government employees. The participants were selected using accidental sampling technique across the sixteen local government areas in Ekiti State, Nigeria. Thus, they were two hundred and seven (207) altogether. One hundred and twenty eight $(61.8 \%)$ of the participants were females and seventy nine $(38.2 \%)$ were males. Ages of participants showed that $21(10.1 \%)$ of them fell within the age range of 20-29 years. $135(65.2 \%)$ fell within the age range of 30-39 years and 51(24.6\%) fell within 40 years and above. In term of educational qualifications, 35(15.9\%) of the participants had Ordinary National Diploma (OND), 77(37.2\%) had Higher National Diploma (HND), 71(34.3\%) had Bachelors' Degree (B.Sc., B.A., B.ED, B. Eng etc), 11(5.3\%) had Masters' Degree, and 15(7.2\%) had other qualifications such Secondary School Certificate and Technical College Certificate. The positions (job status) and grade levels of participants showed that $39(18.8 \%)$ of the participants are between the grade levels of 1-6 (junior officers), 148(71.5\%) are on grade levels 7-14 (middle level officers), while a partly 20 (9.7\%) are on grade levels 15-17 (top level officers).

\section{Variables}

The independent variables in the study are Job Status, Gender, and Achievement Motivation Behavior; while the dependent variable is Work Performance.

\section{Research Design}

Owing to the nature of the present study, factorial design was adopted. The design made it possible to test for the individual and interaction effects of the identified independent variables on the dependent variable.

\section{Measures}

A questionnaire consisting of three sections was used to collect data for the study. Section 'A' of the questionnaire is comprised of personal biographical questions such as age, gender, educational qualification, job status, and salary grade level of research participants. Section 'B' is comprised of the 14 item measure of achievement motivation developed by Ray (1979). The scale requires research participants to express their degree of agreement with statement items which consist of Yes/No responses. The responses are scored as '2' for every 'Yes' response and ' 1 ' for every 'No' response. Items $1,2,7,11$, and 13 on the scale are reverse scored and the author reported an internal consistency alpha coefficient of 0.77 (split half) reliability and 0.71 for its validity. Section ' $C$ ' of the questionnaire measures perceived work 
performance using the 10 items scale developed by Brown and Leigh (1996). The measure is a self-rating scale which tries to measure how each participant feels she/he is performing her/his duties. Participants were expected to express their degree of agreement with statements on the measure on a 5-point Likert type scale. However, the degree of responses varies from 'strongly agree' scored as 5 points through 'agree' scored as 3 points to 'strongly disagree' scored as 1 point. The scale has coefficient alpha of 0.82 and measures the employees' characteristic tendencies to work long and hard as a means of achieving success, rather than engage in other activity during a specific time period.

\section{Method of Statistical Analysis}

The seven hypotheses generated in the study were tested using the two by two by three Analysis of Variance (ANOVA). However, this follows the levels of the independent variables i. e. gender (male/female), achievement motivation (high/low), and job status (junior level, middle level, and top level).

\section{Results} below.

The results of the statistical analysis of the collected data are presented Table 1.2 by 2 by 3 Analysis of Variance (ANOVA) table showing the individual and joint effects of job status, gender, and employees' achievement motivation behavior on their work performance.

\begin{tabular}{|c|c|c|c|c|c|}
\hline Source & Sum of square & $\mathrm{df}$ & $\begin{array}{c}\text { Mean } \\
\text { Square }\end{array}$ & $\mathrm{F}$ & $\mathrm{P}$ \\
\hline Sex (A) & 0.091 & 1 & 0.091 & 0.005 & $>.05$ \\
\hline Job Status (B) & 168.197 & 2 & 84.099 & $5.050^{*}$ & $<.05$ \\
\hline $\begin{array}{c}\text { Achievement } \\
\text { motivation (C) }\end{array}$ & 38.902 & 1 & 38.902 & $2.336^{*}$ & $<.05$ \\
\hline A\&B & 92.260 & 2 & 46.130 & $2.770^{*}$ & $<.05$ \\
\hline A\&C & 8.777 & 1 & 8.777 & $0.527^{*}$ & $<.05$ \\
\hline B\&C & 93.871 & 2 & 46.935 & $2.818^{*}$ & $<.05$ \\
\hline A\&B\&C & 7.243 & 2 & 3.621 & 0.217 & $>.05$ \\
\hline Error & 3247.527 & 195 & 16.654 & & \\
\hline Total & 3689.304 & 206 & & & \\
\hline
\end{tabular}

From the table above, the results revealed that employees' job status has a significant main effect on work performance among local government workers $[\mathrm{F}(2,206)=5.050 ; \mathrm{p}<.05]$.

Result from the table above also revealed that achievement motivation has a significant main effect on work performance $[F(1,206)=2.336 ; p<.05]$. 
Result from the table further revealed that there is a significant interaction effect of gender and job status on the work performance of local government workers $[\mathrm{F}(2,206)=2.770 ; \mathrm{p}<.05]$.

Result from the table above equally revealed that there is a significant interaction effect of gender and achievement motivation on the work performance of local government workers $[\mathrm{F}(1,206)=0.527 ; \mathrm{p}<.05]$.

Result from the table above also shows that there is a significant interaction effect of job status and achievement motivation on the work performance of local government workers $[\mathrm{F}(2,206)=2.818 ; \mathrm{p}<.05]$.

From the table above, the $2 \times 2 \times 3$ ANOVA result showed that there was no significant interaction effect of gender, job status, and achievement motivation behavior on work performance $[\mathrm{F}(2,206)=0.217 ; \mathrm{p}>.05]$. Also, no significant effect of gender is found to exist on the work performance of local government employees $[\mathrm{F}(1,206)=.005, \mathrm{p}>.05]$.

\section{Discussion of results, conclusion and recommendation Discussion}

The results of data analysis from the table above indicated that sex(male/female) does not have any significant influence on the work performance of Local Government employees in Ekiti State. This result implies that irrespective of the sex of the employees, they all perform their jobs almost similarly. This finding negates earlier findings and arguments that the place of the girl child or woman is in the homes and kitchen where she is responsible for bearing and rearing children and maintaining the welfare of the family and as such stigmatized as lazy or incompetent to be hired by employers of labour (e.g. Umar, 1996; Broverman et al.,1970; Ogunleye, 2006; Abbas, Hameed \& Waheed, 2011). Furthermore, Maccoby and Jackling (1974) also posit that gender differences existed between males and females in four major areas which are: i. Verbal ability, ii. Visual and spacial ability, iii. Mathematical ability, and iv. Aggressiveness. In a similar vein, Hoffman (1977) reported that whereas males are hard working, intelligent, ambitious, aggressive and independent, females are kind, loving, and attractive. Therefore, this is in line with societal expectations for both sexes.

Nevil and Schlecker (1988), however, found out that self-efficacy and assertiveness were related to a willingness to engage in non-traditional career related activities. Whiston (1993), therefore, submit that women in nontraditional careers have higher self-efficacy for working with people when compared with women in the traditional professions. One is therefore apt to conclude that men and women in Local Government employment in Ekiti State do not differ in their work performance because of the non-traditional nature of works in the Local Government commission and a higher selfefficacy and assertiveness of the women. 
Findings from the present study also revealed that job status (position of employees either as junior, middle level, or top level officers) significantly influences work performance. A consideration of the mean (x) scores indicated that junior level officers $(x=40)$ seem to perform harder/better than their middle level officers $(x=38)$ and top level $(x=37)$ counterpart officers, respectively. This finding is in consonance with the position of Barankay (2012) who opined that rank incentives have a significant impact on work performance. In a similar vein, Bernstein and Xin Li (2016) posit that seeing where one stands in the workplace provides some form of feedback which impacts performance. Furnham (1992) also explained that job status is often identified as one of the factors that influence one's perception towards one's job. With this thought in mind, a subordinate employee may perceive her/his job as an avenue of starting a career in life. As a result, she/he tries to work harder, whereas the senior manager who has been in the job process for some times may be somehow lackadaisical about the job and as such become less productive. Roussean (2000) suggests that senior managers are more likely to be transactionally oriented in their psychological contract than task oriented. Transactional orientation may therefore result in low level of work performance. This occurs particularly when incentives from work are not perceived as commensurate with efforts or status on the job, or satisfying.

The hypothesis that achievement motivation will affect employees' work performance was also tested given the premise that empowerment and recognition, good intention, self-devotion, and extra role behavior (components of contextual performance, according to Hurt \& Donovan, 2000) have been indicted to influence performance. Therefore, the results of data analysis revealed that achievement motivation significantly influences job performance. This finding is in line with previous research findings (e.g. Tutar, Altinoz \& Cakiroglu, 2011; Dobre, 2013; Muogbo, 2013). Workers achievement motivation is based on reaching success and achieving aspirations in life. According to Harackiewicz, Barron, Carter, Lehto and Elliot (1997), achievement goal can affect the way a person performs a task and represent a desire to show competence. McClelland (1985) posit that achievement motive refers to the desire to do well relative to the standard of excellence. Workers with high achievement motivation will thus tend to be more realistic in their career aspirations and consequently work harder and better than their counterparts with low achievement motivation.

Results from data analysis from present study also revealed a significant interactive influence of sex and job status on work performance.

Although no significant influence of sex was found on job performance in the present study, the interactive influence of sex and job status found here could be linked to personality characteristics and the skills of the participants. For example, Scheresky (1976) found out that the prestige level 
of various personal characteristics, including gender, associated with occupation was frequently cross culturally stereotyped. Thus, workers in the Local Government service commission in Ekiti State may have been influenced by the cultural/societal beliefs. Hence, irrespective of their sex, they may either be motivated to work harder to gain more prestige and self esteem or they may choose to reduce efforts on their job owing to having attained a status on the job.

Results of data analysis also revealed that sex and achievement motivation interactively affect work performance of Local Government employees. Although no significant effect of sex on work performance was reported in this study, the significant contributory effect of these two variables, jointly, on work performance may be attributed to the role sex and achievement motivation may play in ensuring optimum performance in the work place. For example, existing literature is replete with consistent report of significant gender differences in work performance (e.g. Green, Jegadesti \& Tang, 2009; Nierdele \& Vesterlund, 2006; Esmail, Bhambani \& Brintnell, 1995). In the same vein, various studies (e.g. Singh \& Shrivatava, 1983; Orphen, 2007; Brunstein \& Maier, 2005), including the present study, have reported a patterned effect of achievement motivation on work performance. Corroborating this are Atkinson and Feather (1966) who jointly submitted that achievement motivation is a talent disposition which is manifested in overt striving towards ensuring excellence at activities conceived to be under control and coordination.

Findings from the present study also showed that job status and achievement motivation jointly influence the work performance of Local Government employees. This may not be unconnected to the fact that job status (which is an extrinsic motivator) and achievement motivation (intrinsic motivator) may both serve as strong motivators for optimum performance on the job. For example, junior workers may perform optimally to boost their profiles, while senior employees may exhibit high performance on the job due to their affective commitment to the job and workplace. The intrinsic motivation of dispositional need for achievement could spur an employee on when external factors lose their grip.

Another inference drawn from the results of this study is that there is no significant interaction effect of sex, achievement motivation, and job status on the work performance of Ekiti State Local Government employees.

Subsequently, there seem to be no existing research that had investigated the effect of these three variables on work performance simultaneously. The finding of the present study may thus serve as an eye opener and impetus for further researches in this area. 


\section{Conclusion}

Based on the findings of this study, it can be empirically concluded that:

1. There is a significant effect of employees' job status and achievement motivation on work performance.

2. There is no significant main effect of sex on job performance among Ekiti State Local Government workers.

3. There is a significant interaction effect of sex and job status on employees' work performance.

4. There is a significant interaction effect of sex and achievement motivation on work performance.

5. There is a significant interaction effect of job status and achievement motivation on work performance.

6. There is no significant interaction effect of sex, job status, and employees' achievement motivation on work performance.

\section{Recommendation}

Since this study has found that job status positively impact performance, promotion of workers should be merit-based so as to serve as a motivator to the employees, while also putting them on their toes to work harder to earn due promotions.

Organizations, during the recruitment processes, should also be on the lookout for job applicants with high intrinsic motivation for achievement. This should be such that prospective employees will likely put in worthwhile efforts towards the attainment of organizational goals.

In addition, concerted efforts should also be made to ensure equal employment opportunities for both sexes as there seem to be no significant sex differences in job performance. The 'glass ceiling effects' whereby females are denied opportunities of reaching the pinnacle of their careers in certain occupations owing to societal expectations and stereotypic beliefs should be eradicated.

\section{References:}

Abbas, Qaisar, Hameed, Abdul, Waheed, \& Aamer (2011). Gender Discrimination and its Effects on Employees Performance/Productivity. International Journal of Humanities and Social Science, 1(15): 170-176. Adana, B.S. (1986). Job Finding. In T. Ipaye. (Ed). Education and Vocational Guidance: Concepts and Approaches. Ibadan: Bezekos.

Adeyemo, D.A. \& Aremu, A.O. (1999). Career commitment among Secondary School Teachers in Oyo State: the Biographical Mediators in Nigeria. Journal of Applied Psychology, 5(2): 184-194 
Ajala, A. A. (2004). The influence of gender factors on managerial effectiveness in Oyo State, Nigeria. Unpublished Ph.D. Dissertation, University of Ibadan.

Ajayi, I, A. \& Oguntoye, H. O. (2003). Motivation as correlate of teachers' job performance of Ogun State Secondary Schools. Journal of Education, (3): 155-162.

The Annual Abstract of Statistics (1997). Federal Office of Statistics, Abuja, Nigeria.

Barankay, I. (2012). Rank Incentives: Evidence From a Ramdomized Workplace Experiment. Available at: www.cep.ise.ac.uk/seminarpapers/0410-12.pdf.

Bernstein, E. S. \& Xin Li, Shelley (2016). Seeing where you Stand: From Performance Feedback to Performance Transparency. Available at: https://www.gsb.stanford.edu/.../ob_04_...

Blumberg, M. \& Pringle, C. D. (1982). The missing opportunity in organizational research: Some implications for a theory of work performance. Academy of Management Review, 7(4): 560-569.

Broverman, I.K., Broverman, D.M., Clarkson, K.T., Rosenkrants, P.S. \& Vogel, S. R. (1970). Sex role stereotypes and clinical judgment of mental health personnel. Journal of counselling and Clinical Psychology, 38: 1-7

Brown, C \& Corcoran, M. (1997). Sex-Based differences in school content and the male-female wage gap. Journal of Labour Economics, 15: 431-465.

Brown, S. P. \& Leigh, T. W. (1996). A new look at psychological climate and its relationship to job involvement, effort, and performance. Journal of Applied Psychology, 81:358-368.

Brunstein, J. C. \& Maier, G. W. (2005). Implicit and Self Attributed Motives to Achieve: Two separate but interacting needs. Journal of Personality and Social Psychology, 89: 205-222.

Champion, D, J., Kurt, S. E., Hastings, D. W., \& Harris, D. K. (1984). Sociology. New York: Holt, Rinehart and Winston.

Clark, S. C. (2000). Work/family border theory: A new theory of work/family balance. Human Relations, 53: 747-770

Dalton, G. W., Thompson P.H., \& Price, R. (1977). The four stages of professional careers: A new look at performance by profession. Organizational Dynamics, 6(1): 19-42.

Dobre Ovidin-Iliuta (2013). Employee Motivation and Organizational Performance. Review of Applied Socio-Economic Research, 5(1): 53-60.

Esmail, E., Bhambani, Y. \& Brintnell, S. (1995). Gender Difference in Work Performance on the Baltimore Therapeutic Equipment Work Stimulator. American Journal of Occupational Therapy, 49(5): 405-411.

Fergenson, E. (1990). Perceived masculine and feminine attributes examined as a function of individuals' sex and level in the organizational power 
hierarchy: A test of four theoretical perspectives. Journal of Applied Psychology, 72: 204-21.

Furnham, A. (1992). Personality at Work. New York: Routledge.

Green, C., Jegadesh, N. \& Tang, Y. (2009). Gender and Job Performance: Evidence from Wall Street. Financial Analysts' Journal, 65(6): 48-52.

Harackiewicz. J.M., Barron, E.K., Carter, S.M., Lehto, A.J., \& Elliot, A.J.(1997). Predictors and consequences of achievement goal in the college classroom: Maintaining interest and making the grade. Journal of Personality and Social Psychology, 73:1284-1295.

Hartman, S.J. (1988). The impact of occupation, performance and sex-role stereotyping. Journal of Social Psychology, 128(4): 451-463.

Hoffman, L. (1977). Changes in Family Roles, Socialization, and Sex Differences. American Psychologist, 32: 644-657.

Jamal, M. (1984). Job stress and job performance controversy: An empirical assessment. Organizational Behavior and Human Performance, 32: 1-21

Knudson, A.D. (1982). Young Management Women: A New Look. Journal of NAWDAC, 45(2): 3-9.

Larwood, L. \& Gutek, B. A. (1989). Working towards a women's career development, In B. A. Gutek and L. Larwood (Eds.)(Pgs 170-183), Women's Career Development. New Bury Park, CA: Sage.

Lynn, S. A., Cao, L.T. \& Horn, B. C. (1996). The influence of career stage on the work attitude of male and female accounting professionals. Journal of Organizational Behavior, 17: 135-149.

Maccoby, E.E., \& Jacklin, C.N. (1974). The psychology of sex differences. Stanford C.A.: Stanford University Press.

Maslow, A. H. (1954). Motivation and Personality. New York: Harper and Row.

McClleland, D. C. (1985). How motives, skills and values determine what people do. American Psychologist, 40: 812-825.

Muogbo, Uju S. (2013). The Influence of Motivation on Employees' Performance: A study of some selected firms in Anambra State, Nigeria. AFRREV IJAH Journal of Arts and Humanities, 2(3): 134-151.

Nevil, D. D. \& Schlecker, D. L. (1988). The Relation of Self Efficacy and Assertiveness to Willingness to Engage in Traditional/ Non Traditional Career Activities. Psychology of Women Quarterly, 12: 91-98.

Niederle, M. \& Vesterlund, L. (2006). Do women shy away from competitions? Do men compete too much? Quarterly Journal of Economics, 122(3): 1067-1101.

Niederle, M. \& Vesterlund Lise (2008). Gender differences in competition. Negotiation Journal, Oct. 2008: 447-463. (Doi:10.1111/j.15719979.2008.00197.x) 
Ogunleye, T. O. (2006). Success Anxiety, Job Ability Perception and Social Interaction among Women in Male Dominated Professions: Implications for counseling. Unpublished $\mathrm{Ph}$. D. Dissertation, University of Lagos, AkokaLagos.

Okolo, I. (9 $9^{\text {th }}$ July. 1985). Women in the legal profession in Nigeria: Problem and prospects. Daily Times, P. 5.

Olaoye, R. A. \& Oredein, A.O. (2004). Job satisfaction, Motivation and Performance of South West Nigeria Secondary School Science, Technology and Mathematics Teachers. Journal of Educational Foundation and Management, 4(1): 158-167.

Orestein, S. \& Isabella, L. 1990. "Age versus stage models of career attitudes of women: A partial replication and extension." Journal of Vocational Behaviour, 36:1-19.

Orphen, C. (2007). The Effect of Achievement Motivation on the Relationship between Perceived Job Attributes and Managerial Satisfaction and Performance. International Journal of Psychology, 20(2): 456-459.

Ray, J. J. (1979). A quick measure of achievement motivation-Validated in Australia and reliable in Britain and South Africa. Australian Psychologist, 14(3): 337-344.

Rousseau, D. M. (2000). Psychological Contract Inventory Report (Technical). Pittsburgh, Pennyslavia: Heinz School of Industrial Administration, Carnegie Mellon University.

Scheresky. A. (1976). The gender factor in six to ten year-old children's view of occupational roles. Psychological Reports, 38: 1207-1210.

Sidanius, J. \& Pratto, F. (1999). Social Dominance: An Intergroup Theory of Social Hierarchy and Oppression. Cambridge, United Kingdom: Cambridge University Press.

Singh, A. P. \& Shrivatava, P. (1983). Effect of Need for Achievement on the Job Performance-Job Satisfaction Relationship. Indian Journal of Industrial Relations, 18(3): 437-442.

Tutar, H., Altinoz, M. \& Cakiroglu, D. (2011). The Effects of Employees' Empowerment on Achievement Motivation and the Contextual Performance of Employees. African Journal of Business Management, 5(15): 6318-6329.

Umar, L.K.K. (1996). Education of the girl-child in Northern Nigeria: A case for counselling. The Counsellor, 14(2): 77-83.

Uwe, E. A. (1999). Gender orientation and occupational competence of workers. Paper presented at $23^{\text {rd }}$ Annual Conference of the Counseling Association of Nigeria (CASSON) held at the University of Lagos, from $23^{\text {rd }}$ $-30^{\text {th }}$ of August, 1999.

Whiston, S. C. (1993). Self Efficacy of Women in Traditional and Non Traditional Occupations: Differences in working with people and things. Journal of Career Development, 19(3): 175-186. 